\title{
Precipitation as driver of carbon fluxes in 11 African ecosystems
}

\author{
L. Merbold ${ }^{1}$, J. Ardö ${ }^{2}$, A. Arneth ${ }^{2}$, R. J. Scholes ${ }^{3}$, Y. Nouvellon ${ }^{4,5}$, A. de Grandcourt ${ }^{4,5}$, S. Archibald ${ }^{3}$, \\ J. M. Bonnefond ${ }^{6}$, N. Boulain ${ }^{7}$, N. Brueggemann ${ }^{8}$, C. Bruemmer $^{16}$, B. Cappelaere ${ }^{7}$, E. Ceschia ${ }^{9}$, H. A. M. El-Khidir ${ }^{10}$, \\ B. A. El-Tahir ${ }^{10}$, U. Falk ${ }^{11}$, J. Lloyd ${ }^{14}$, L. Kergoat ${ }^{9}$, V. Le Dantec ${ }^{9}$, E. Mougin ${ }^{9}$, M. Muchinda ${ }^{12}$, M. M. Mukelabai ${ }^{12}$, \\ D. Ramier ${ }^{7}$, O. Roupsard ${ }^{4,15}$, F. Timouk ${ }^{9}$, E. M. Veenendaal ${ }^{13}$, and W. L. Kutsch ${ }^{1}$ \\ ${ }^{1}$ Max-Planck Institute for Biogeochemistry, P.O. Box 100164, 07701 Jena, Germany \\ ${ }^{2}$ Department of Physical Geography and Ecosystems Analysis, Lund University Sölvegatan 12, 22362, Lund, Sweden \\ ${ }^{3}$ Natural Resources and Environment, CSIR, P.O. Box 395, Pretoria, South Africa \\ ${ }^{4}$ CIRAD, Persyst, UPR80, TA B-80/D, 34398 Montpellier Cedex 5, France \\ ${ }^{5}$ UR2PI, BP 1291, Pointe-Noire, Republic of Congo \\ ${ }^{6}$ INRA-EPHYSE, BP 81, 33883 Villenave d'Ornon Cedex, France \\ ${ }^{7}$ UMR Hydrosciences, IRD, BP 64501, 34394 Monpellier Cedex 5, France \\ ${ }^{8}$ Atmospheric Environmental Research Division, Institute of Meteorology and Climate Research, Forschungszentrum \\ Karlsruhe, Garmisch-Partenkirchen, Germany \\ ${ }^{9}$ CESBIO, 18 Avenue Edouard Belin, 31401 Toulouse Cedex 9, France \\ ${ }^{10}$ Agricultural Research Cooperation, El Obeid Research Station, P.O. Box 429, 51111, El Obeid, Sudan \\ ${ }^{11}$ Department of Ecology and Resource Management, Center for Development Research, University of Bonn, Bonn, Germany \\ ${ }^{12}$ Zambia Meteorological Department, Haile Sellasie Avenue, City Airport, P. O. Box 30200, 10101 Lusaka, Zambia \\ ${ }^{13}$ Nature Conservation and Plant Ecology Group, Wageningen University, Droevendaalse Steeg 3a, \\ 6708 PD Wageningen, The Netherlands \\ ${ }^{14}$ Earth and Biosphere Institute, School of Geography, University of Leeds, LS29JT, UK \\ ${ }^{15}$ CATIE, 7170 Turrialba, Costa Rica \\ ${ }^{16}$ Biometeorology and Soil Physics Group, Faculty of Land and Food Systems, University of British Columbia, \\ V6T 1ZA, Vancouver, Canada
}

Received: 1 September 2008 - Published in Biogeosciences Discuss.: 27 October 2008

Revised: 26 May 2009 - Accepted: 5 June 2009 - Published: 18 June 2009

\begin{abstract}
This study reports carbon and water fluxes between the land surface and atmosphere in eleven different ecosystems types in Sub-Saharan Africa, as measured using eddy covariance (EC) technology in the first two years of the CarboAfrica network operation. The ecosystems for which data were available ranged in mean annual rainfall from $320 \mathrm{~mm}$ (Sudan) to $1150 \mathrm{~mm}$ (Republic of Congo) and include a spectrum of vegetation types (or land cover) (open savannas, woodlands, croplands and grasslands). Given the shortness of the record, the EC data were analysed across the network rather than longitudinally at sites, in order to understand the driving factors for ecosystem respiration and carbon assimilation, and to reveal the different water use strategies in these highly seasonal environments.
\end{abstract}

Correspondence to: L. Merbold (lmerbold@bgc-jena.mpg.de)
Values for maximum net carbon assimilation rates (photosynthesis) ranged from $-12.5 \mu \mathrm{molCO}_{2} \mathrm{~m}^{-2} \mathrm{~s}^{-1}$ in a dry, open Millet cropland $\left(\mathrm{C}_{4}\right.$-plants $)$ up to $-48 \mu \mathrm{mol} \mathrm{CO} \mathrm{m}^{-2} \mathrm{~s}^{-1}$ for a tropical moist grassland. Maximum carbon assimilation rates were highly correlated with mean annual rainfall $\left(r^{2}=0.74\right)$. Maximum photosynthetic uptake rates $\left(F p_{\max }\right)$ were positively related to satellite-derived $f_{\mathrm{APAR}}$. Ecosystem respiration was dependent on temperature at all sites, and was additionally dependent on soil water content at sites receiving less than $1000 \mathrm{~mm}$ of rain per year. All included ecosystems dominated by $\mathrm{C}_{3}$-plants, showed a strong decrease in 30-min assimilation rates with increasing water vapour pressure deficit above $2.0 \mathrm{kPa}$.

* Fluxes from the atmosphere to the ecosystem are negative, fluxes from the ecosystem to the atmosphere are positive.

Published by Copernicus Publications on behalf of the European Geosciences Union. 


\section{Introduction}

Information about Africa's role in the global carbon cycle is sparse. It remains unknown whether Africa, as a whole, represents a net sink or source of atmospheric carbon, and how carbon exchange varies temporally and spatially at the continental scale (Williams et al., 2007). Africa supports a large variety of terrestrial ecosystem types, reflecting differences in climate, geology, and species composition, as well as land use and land use change taking place all over the continent.

Three important approaches have been applied recently to understand the variations of $\mathrm{CO}_{2}$ exchange processes of African ecosystems in space and time as well as their drivers. The first focused on the biocomplexity of savannas (Sankaran et al., 2005, 2008; Bucini and Hanan, 2007) and followed a long tradition of ground-based ecophysiological research trying to understand the role of water, nutrients, herbivory and fire in savanna dynamics, and in particular on tree-grass interactions (Walter, 1939, 1971; Scholes and Walker, 1993; Scholes and Archer, 1997; Jeltsch et al., 2000; Scholes et al., 2004; Bond and Keeley, 2005; Bond et al., 2005). This approach supports to interpret functional properties of savannas by understanding their structure.

The second approach has used remote sensing to reveal large-scale vegetation patterns and their properties (Weber et al., 2009). The "eye in the sky" provides indices that can be used to extrapolate in time and space process-oriented knowledge derived by the studies using the first approach. For example, Archibald and Scholes (2007) demonstrated that it is possible to use knowledge of the different life history strategies of trees and grasses to "unmix" their phenologies in low resolution satellite imagery, which is an important step forward towards modelling of carbon and water fluxes at a regional scale.

The third approach, recently summarized by Lloyd et al. (2008), is to develop continental-scale mass balances, constrained by isotope measurements. Williams et al. (2007) reviewed what these studies reveal about Africa. This approach is of particular importance for the partitioning between ocean-atmosphere exchanges and land-atmosphere exchanges in global carbon cycle studies, because the relatively low natural photosynthetic discrimination $(\Delta)$ of $\mathrm{C}_{4}$ grasses is similar to that accompanying air-to-sea $\mathrm{CO}_{2}$ exchange (Lloyd and Farquhar, 1994).

These approaches suggest that the most important pattern driving structure and function of African ecosystems is rainfall (Williams et al., 2007), but a number of additional processes, like fire, herbivory and soil fertility, need also to be considered.

We suggest that analysis of variation in ecosystematmosphere exchange of carbon dioxide and water measured by eddy covariance, can be a fourth approach to understanding the structure and function of African ecosystems and unravelling the role of Africa in the global carbon cycle. To date, such information has been scarce. A limited number of eddy covariance-based analyses of seasonal variation of ecosystem-atmosphere carbon exchange have been published over the last few years, describing single ecosystem types such as Mopane woodlands (Colophospermum mopane), broad-leaved deciduous Combretum-dominated savannas, fine-leaved Acacia-dominated savannas, as well as plantations of clonal Eucalypt in tropical Africa (Goutorbe et al., 1997; Hanan et al., 1998; Epron et al., 2004, 2006; Veenendaal et al., 2004; Arneth et al., 2006; Bruemmer et al., 2008; Kutsch et al., 2009). Some studies that seek to provide a broader integration over latitude or along rainfall gradients have been based on short-term campaign measurements (Dolman et al., 1997; Dolman et al., 2003; Scanlon and Albertson, 2004; Scholes et al., 2004; Shugart et al., 2004; Schuttemeyer et al., 2006).

In this study, we compare ecosystem fluxes across a range of vegetation types and climate zones. We focus specifically on the flux response to variations in precipitation during the wet season. We seek to test whether precipitation and soil moisture are not only a principle determinant of the distribution of vegetation types in Africa, but also the overriding environmental controls on the spatial variation in Net Ecosystem Exchange of carbon (NEE). Furthermore, we investigate whether NEE-soil moisture relationships known from observations in drought-stressed temperate (Mediterranean) or boreal ecosystem that contain only $\mathrm{C}_{3}$ species are also found in tropical ecosystems with their variable mix of $\mathrm{C}_{3}$ and $\mathrm{C}_{4}$ photosynthetic systems, and rainfall rather than temperaturecontrolled seasonality.

\subsection{Material and methods}

\subsubsection{Study sites}

Eddy covariance data for at least a full year were available for eleven sites, distributed over Sub-Saharan Africa. These sites are either part of or associated with the CarboAfrica network (a newly-established part of the global Fluxnet community, with strong affiliations to the CarboEurope network). Associated sites have been parts of other internationally or nationally funded projects that are listed in the Acknowledgements.

The Sub-Saharan region is that part of Africa south of the Sahara desert, including the grasslands, shrublands and savannas of Western, Eastern and Southern Africa, and the forests and woodlands of Central Africa (Hudman and Jackson, 2002), as well as a range of derived land uses such as croplands and tree plantations. The study covers ecosystems from the very dry Sahel (Sudan, Mali and Niger), to the semiarid and sub-humid regions in Southern Africa (Botswana, Zambia and South Africa; Scholes et al., 2004) and to the humid environments towards the equator (Republic of Congo, see Fig. 1 and Table 1 for details). The study areas differ in ecosystem type, seasonality and mean annual rainfall. Except the tropical rainforests of the Congo Basin, the most extensive ecosystem types in Sub-Saharan Africa, as Mopane 
Table 1. Basic site information, including location, altitude in m, mean annual air temperature (MAT), mean annual rainfall (MAP), ecosystem type with the dominant species, information about $\mathrm{C} 3 / \mathrm{C} 4$ distribution, protective state and soil classification.

\begin{tabular}{|c|c|c|c|c|c|c|c|c|c|c|}
\hline Site and publiation (No in Fig. 1) & Country & Coordinates & Altitude in $\mathrm{m}$ & MAT in ${ }^{\circ} \mathrm{C}$ & MAP in mm & Ecosystem & Dominant species & $\mathrm{C} 3 / \mathrm{C} 4$ cover & Protective state & Soil type \\
\hline Demokeya (4) Sjöström et al., 2008 & Sudan & $13.2829 \mathrm{~N}, 30.4783 \mathrm{E}$ & 500 & 26 & 320 & Sparse acacia savanna & $\begin{array}{l}\text { Acacia spp., Aristida pallida, } \\
\text { Eragrostits tremula and } \\
\text { Cenchrus biflorus }\end{array}$ & $30 / 70$ & Protected but not fenced & $\begin{array}{l}\text { Cambic } \\
\text { Arenosol }\end{array}$ \\
\hline Agoufou (10) & Mali & $15.34322 \mathrm{~N}, 1.48067 \mathrm{~W}$ & 290 & 29.7 & 350 & Open woody savanna & $\begin{array}{l}\text { Acacia spp., Balanites aegyptiaca, } \\
\text { Combretum glutinosum }\end{array}$ & $25 / 75$ & Unprotected, cattle grazing & $\begin{array}{l}\text { Sandy ferruginous } \\
\text { Arenosol }\end{array}$ \\
\hline Kelma (11) & Mali & $15.22370 \mathrm{~N}, 1.56620 \mathrm{~W}$ & 273 & 29.6 & 650 (300 inflow) & Acacia woodland & Acacia seyal & $90 / 10$ & $\begin{array}{l}\text { Unprotected, occasional } \\
\text { cattle grazing }\end{array}$ & Clay soil depression \\
\hline Maun (2) Veenendaal et al., 2004 & Botswana & $19.9275 \mathrm{~S}, 23.5672 \mathrm{E}$ & 950 & 22 & 464 & Mopane woodland & Colosphermum mopane & $80 / 20$ & $\begin{array}{l}\text { Unprotected, cattle } \\
\text { grazing, fire wood }\end{array}$ & Kalahari sands \\
\hline Skukuza (1) Kutsch et al., 2008 & South Africa & $25.0197 \mathrm{~S}, 31.4969 \mathrm{E}$ & 359 & 21.9 & 547 & $\begin{array}{l}\text { Broadleafed and } \\
\text { fineleafed savanna }\end{array}$ & Combretum sp. Acacia sp. & $30 / 70$ & Kruger National Park & $\begin{array}{l}\text { Sandy clay loam } \\
\text { Arenosol }\end{array}$ \\
\hline $\begin{array}{l}\text { Wankama (8) (Millet) } \\
\text { Boulain et al., } 2008\end{array}$ & Niger & $13.6474 \mathrm{~N}, 2.6298 \mathrm{E}$ & 244 & 28.5 & 560 & Millet crop & Pennisetum glaucum & $10 / 90$ & Crop field & $\begin{array}{l}\text { Sandy ferruginous } \\
\text { Arenosol }\end{array}$ \\
\hline $\begin{array}{l}\text { Wankama (9) (Fallow) } \\
\text { Ramier et al., } 2008\end{array}$ & Niger & $12.6475 \mathrm{~N}, 2.6336 \mathrm{E}$ & 235 & 29.5 & 560 & Fallow bush & $\begin{array}{l}\text { Guiera senegalensis } \\
\text { Zornia glochidiata }\end{array}$ & $80 / 20$ & Fallow bush & $\begin{array}{l}\text { Sandy ferruginous } \\
\text { Arenosol }\end{array}$ \\
\hline Bontioli (7) Bruemmer et al., 2008 & Burkina Faso & $10.18222 \mathrm{~N}, 3.67277 \mathrm{~W}$ & 293 & 29.5 & 926 & Grass- and shrubland & $\begin{array}{l}\text { Andropogon ayanus, } \\
\text { Loudetiopsis kerstingii }\end{array}$ & $70 / 30$ & Nature reserve & Sandy loam \\
\hline $\begin{array}{l}\text { Mongu (3) Scanlon } \\
\text { and Albertson, } 2004\end{array}$ & Zambia & $15.4377 \mathrm{~S}, 23.2527 \mathrm{E}$ & 1053 & 24.6 & 945 & Miombo woodland & $\begin{array}{l}\text { Brachystegia bakeriana, } \\
\text { Brachystegia spiciformis }\end{array}$ & $95 / 5$ & Protected forest reserve & Kalahari sands \\
\hline Kissoko (6) Marsden et al., 2008 & Rep. of Congo & $4.7914 \mathrm{~S}, 11.9822 \mathrm{E}$ & 108 & 23.5 & 1076 & $\begin{array}{l}\text { Clonal Eucalyptus } \\
\text { plantation }\end{array}$ & $\begin{array}{l}\text { Urograndis (E. urophylla } \\
x E \text { Erandis) }\end{array}$ & $100 / 0$ & Plantation & Ferralic Arenosol \\
\hline Tchizalamou (5) & Rep. of Congo & $4.2892 \mathrm{~S}, 11.6564 \mathrm{E}$ & 82 & 25.7 & 1150 & Grassland & Loudetia sp., Ctenium newtonii & $0 / 100$ & unprotected & Ferralic arenosol \\
\hline
\end{tabular}

Table 2. Table 2 shows information about the different Eddy covariance setups, as well as the amount of data relevant for analysis (number of night and day time values) and lower/upper thresholds of friction velocity $\mathrm{u}^{*}$

\begin{tabular}{|c|c|c|c|c|c|c|}
\hline Site & $\begin{array}{l}\text { Measuring } \\
\text { height in } \mathrm{m}\end{array}$ & Gas analyzer & Sonic anemometer & Years of measurements & $\begin{array}{l}\text { thresholds of friction } \\
\text { velocity } \mathrm{u}^{*} \text { (low/up) }\end{array}$ & $\begin{array}{l}\text { Number of } 30 \mathrm{~min} \text { data - } \\
\text { Total (night/day) }\end{array}$ \\
\hline Demokeya & 9 & LiCor 7500 & GILL R3 (GILL Instruments Ltd.) & $2005 / 2007$ & $0.15 / 0.5$ & $2681(1925 / 756)$ \\
\hline Agoufou & 4.2 & LiCor 7500 & Csat-3 (Campbell Scientific) & 2007 & $0.15 / 0.4$ & $1652(1353 / 299)$ \\
\hline Kelma & 12 & LiCor 7500 & Csat-3 (Campbell Scientific) & $2007 / 2008$ & $0.05 / 0.6$ & $1801(1089 / 712)$ \\
\hline Maun & 13.5 & LiCor 6262 & GILL R3 (GILL Instruments Ltd.) & $2000 / 2001$ & $0.15 / 0.65$ & $4584(2896 / 1688)$ \\
\hline Skukuza & 16 & LiCor 6262 & Gill Windmaster Pro (GILL Instruments Ltd.) & 2003 & $0.15 / 0.65$ & $426(115 / 311)$ \\
\hline Wankama Millet & 5.1 & LiCor 7500 & Csat-3 (Campbell Scientific) & $2005 / 2006$ & $0.1 / 0.55$ & $6552(4428 / 2124)$ \\
\hline Wankama Fallow & 4.95 & LiCor 7500 & Csat-3 (Campbell Scientific) & $2005 / 2006$ & $0.05 / 0.5$ & $4706(3580 / 1126)$ \\
\hline Bontioli & 2.65 & LiCor 7500 & Csat-3 (Campbell Scientific) & $2004-2006$ & $0.05 / 0.45$ & $3464(2096 / 1368)$ \\
\hline Mongu & 19.5 & LiCor 7000 & GILL R3 (GILL Instruments Ltd.) & $2007 / 2008$ & $0.2 / 0.7$ & $2139(745 / 1394)$ \\
\hline Kissoko & 23.25 & LiCor 7500 & Young $81000 \mathrm{~V}$ (R. M. Young Company) & $2005 / 2006$ & $0.15 / 0.5$ & $5445(442 / 5003)$ \\
\hline Tchizalamou & 3.8 changing & LiCor 7500 & Young $81000 \mathrm{~V}$ (R. M. Young Company) & $2006 / 2007$ & $0.05 / 0.3$ & $1179(471 / 708)$ \\
\hline
\end{tabular}

woodlands (Colosphermum mopane), Miombo woodlands (Brachystegia spiciformis), fine-leafed Acacia savanna (e.g. Acacia senegal, Acacia nigrecens), broad-leafed Combretum savanna (Combretum apiculatum) and a typical grassland in Congo (Loudetia sp, Ctenium newtonii.), as well as a eucalyptus plantation (Eucalyptus sp. clone) are represented in this study.

\subsubsection{Technical setup and data post-processing}

All sites were equipped with eddy covariance equipment (Aubinet et al., 2000; Baldocchi et al., 2000, 2001a) (Table 2). Roughly, each system included a 3-D sonic anemometer (Solent R3 or Windmaster Pro, Gill Instruments, Lymington, UK; CSAT-3 sonic anemometer, Campbell Scientific, Logan, UT, USA; Young 81000V, R. M. Young Company, MI, USA) and an infrared gas analyser (LI-6262/7000/7500, LiCor Inc., Lincoln, NE, USA). Eight sites used an open path and three a closed path system. Disadvantages of the open path system (Webb et al., 1980; Webb, 1982; Leuning and Moncrieff, 1990; Leuning, 2007; Serrano-Ortiz et al., 2008) were balanced by its low power consumption, a great advantage in remote regions. At all sites the EC systems were complemented with meteorological sensors (air temperature, humidity, radiation, rainfall, soil water content etc). Tower height ranged from $3.8 \mathrm{~m}$ (grassland in the Congo) up to $30 \mathrm{~m}$ (woodland in Zambia). A total equivalent to 21 years of EC data were used for this synthesis. The data were all collected between the years 2000 and 2008. Some years only contained a few weeks of appropriate data. Nevertheless, each site was represented by data from the dry as well as the wet season (Veenendaal et al., 2004; Epron et al., 2006).

Half hour flux averages were calculated using various software packages (EdiRe, Eddysoft, Ecoflux and Eddy_PPC). Even though standardized quality criteria (Papale et al., 2006; Kolle and Rebmann, 2007) were applied by each site coordinator, data sets were again screened and filtered for missing and uncertain values. In addition, $\mathrm{u}^{*}$-filtering was applied at nighttime (Goulden et al., 1996; Gu et al., 2005; Papale et al., 2006). Data were also filtered for an upper $\mathrm{u}^{*}$ threshold (Fig. 2) to avoid overestimation of the measured fluxes (Gu et al., 2005; Merbold et al., in press). All thresholds are given in Table 2. 
Table 3. Coefficients determined for analysis (Eqs. 1-3, see also Fig. 3). Peak season averages of ER are given for all sites. Values for $F p_{\text {max }}$ were fitted by quantile regression to derive an envelope (95\%) for each site - see material\&methods, data post-processing. Photosynthetic flux at $R_{g}=0$ is assumed to be $0 . f_{\text {APAR }}$ were 10 day averages, of the peak wet season for each site \pm SD. Peak leaf area index (LAI) were obtained by ground based measurements.

\begin{tabular}{|c|c|c|c|c|c|c|c|c|c|}
\hline Site & $\begin{array}{l}\text { Peak wet season averages } \\
\text { of ER }\left(\mu \mathrm{mol} \mathrm{m}-2 \mathrm{~s}^{-1}\right)\end{array}$ & $r^{2}$ & $n(\mathrm{ER})$ & $F p_{\max }$ & Coefficient $d$ & $n(F p)$ & $\begin{array}{c}\text { Peak } f_{\text {APAR }} \\
\text { by JRC (10 day averages, } 1 \text { pixel })\end{array}$ & $n\left(f_{\mathrm{APAR}}\right)$ & Peak LAI \\
\hline Demokeya & 3.01 & 0.36 & 1925 & 18 & 0.07 & 756 & $0.14 \pm 0.01$ & 4 & 1 \\
\hline Agoufou & 3.71 & 0.53 & 1353 & 23 & 0.055 & 299 & $0.18 \pm 0.09$ & 44 & 1.2 \\
\hline Maun & 3.40 & 0.42 & 2896 & 23.5 & 0.06 & 1688 & $0.3 \pm 0.02$ & 22 & 1.1 \\
\hline Skukuza & 3.51 & 0.64 & 1261 & 19 & 0.05 & 1027 & $0.23 \pm 0.02$ & 13 & 1 \\
\hline Wankama Millet & 2.07 & 0.14 & 4428 & 12.5 & 0.04 & 2124 & $0.12 \pm 0.02$ & 2 & 0.65 \\
\hline Wankama Fallow & 3.48 & 0.20 & 3580 & 22 & 0.07 & 1126 & $0.12 \pm 0.02$ & 2 & 0.9 \\
\hline Kelma & 4.52 & 0.20 & 1089 & 32 & 0.5 & 712 & $0.27 \pm 0.05$ & 13 & 1.1 \\
\hline Bontioli & 4.00 & 0.36 & 2096 & 36 & 0.13 & 1368 & $0.4 \pm 0.02$ & 3 & 3.2 \\
\hline Mongu & 7.10 & 0.26 & 745 & 27.5 & 0.095 & 1394 & $0.37 \pm 0.01$ & 56 & 1.6 \\
\hline Kissoko & 4.26 & 0.08 & 442 & 34 & 0.19 & 5003 & $0.61 \pm 0.12$ & 3 & 2.85 \\
\hline Tchizalamou & 4.36 & 0.49 & 471 & 48 & 0.16 & 708 & $0.3 \pm 0.05$ & 3 & 2 \\
\hline
\end{tabular}

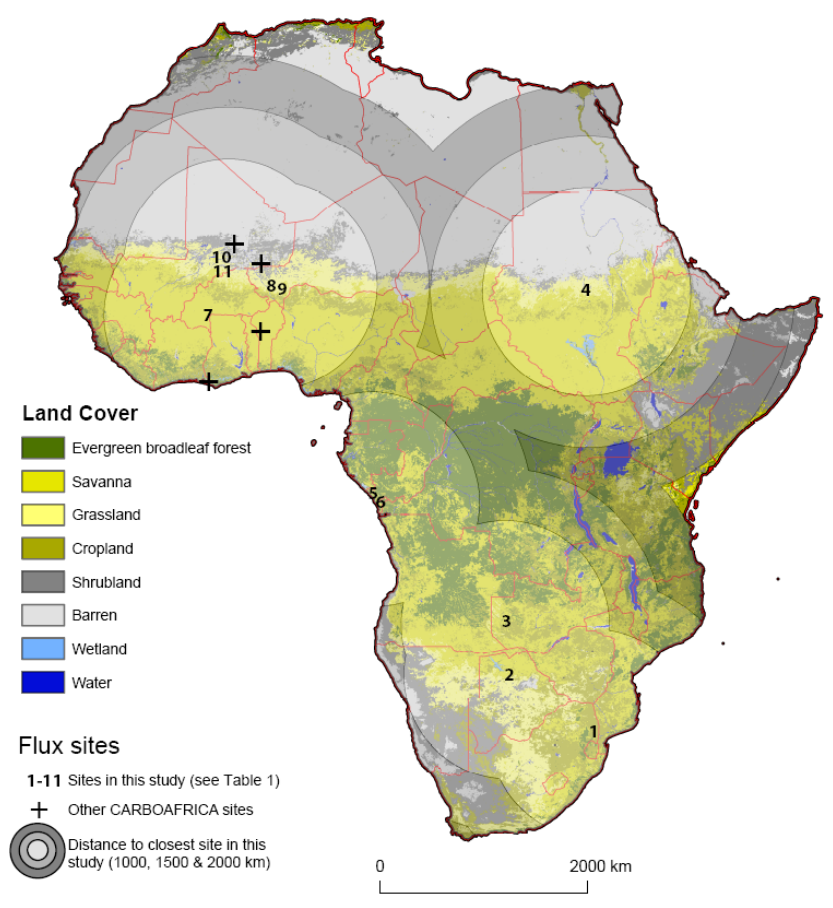

Fig. 1. The most common land cover types in Africa and the locations of eddy-covariance towers run by CarboAfrica and others. "111 " indicate sites included in this study (for more information see Table 1), while other sites are shown as "+" (Data from Global Land Cover Characterisation http://edcsns17.cr.usgs.gov/glcc/glcc.html).

\subsubsection{Flux partitioning and ecosystem-physiological pa- rameters}

Soil water content and temperature are important variables controlling ecosystem respiration (Hanan et al. 1998; Anthoni et al., 2004; Reichstein et al., 2005; Trumbore, 2006). To analyse the response of ecosystem respiration (ER) to these factors, half hourly night time fluxes (filtered) were

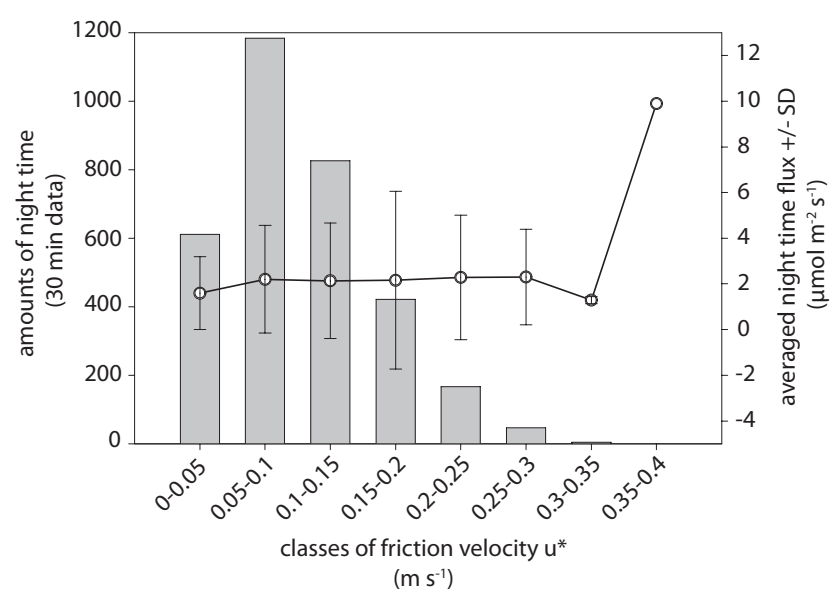

Fig. 2. An example from grassland site at Tchizalamou, Congo, showing how $\mathrm{u}^{*}$ thresholds were defined. The left Y-axis shows the number of $30 \mathrm{~min}$ intervals for each $\mathrm{u}^{*}$ star class and the right Y-axis shows the averaged flux for each class \pm SD. For $\mathrm{u}^{*}<0.05$, the average flux is depressed. These data were rejected as they lead to underestimation. For $0.05<\mathrm{u}^{*}<0.3$ the average flux is stable and used in the analysis. For $\mathrm{u}^{*}>0.3$ the averaged fluxes are exaggerated, leading to overestimation, and were rejected too.

used to represent ER. For all sites, except the two Congolese sites, data of soil temperature at $5 \mathrm{~cm}$ depth and data of relative plant available water were fitted into the model according to Reichstein et al. (2003, Eq. 1).

$E R=R_{\text {ref }} \times f\left(T_{\text {soil }}\right.$, RPAW $) \times g($ RPAW $)$

where $E R$ is the modelled respiration, $R_{\text {ref }}$ is the respiration for a site-specific temperature coefficient during the peak wet season (Table 3), $f$ and $g$ are functions for the influence of soil temperature $\left(T_{\text {soil }}\right)$ and relative plant available water (RPAW). A detailed explanation of these functions can be found in Reichstein et al. (2003), who hypothesized that, in 
addition to a direct influence of soil water status (function $g($ RPAW $)$ ) the sensitivity of the temperature response varies with relative plant available water (function $f\left(T_{\text {soil }}\right.$, RPAW)). Soil temperature was given in ${ }^{\circ} \mathrm{C}$ and RPAW as the fraction of soil water available to plants as explained by Kutsch et al. (2008).

Data from the two Congolese sites, receiving more than $1000 \mathrm{~mm}$ of annual rainfall, were statistically analysed for temperature using an exponential growth function (Eq. 2):

$E R=m e^{\left(T_{\mathrm{air}}-T_{0}\right)}$

where $T_{\text {air }}$ is the air temperature in ${ }^{\circ} \mathrm{C}, m$ and $T_{0}$ are coefficients.

Daytime ecosystem respiration was calculated by Eq. (1) and (2). Canopy photosynthesis $(F p)$ was calculated by subtracting calculated respiration from measured values of net ecosystem exchange (NEE, Eq. 3):

$F p=\mathrm{NEE}-E R$

Canopy photosynthesis was then fitted to a hyperbolical response function of measured global (ie direct plus diffuse) radiation (4) using quantile regression (Cade et al., 2005; Kutsch et al., 2008) to derive an envelope for each site. The envelope function was defined to include $95 \%$ of the observations:

$F p=\left[F p_{\max } \times \tanh \left(d \frac{R_{g}}{F p_{\max }}\right)\right] \times(-1)$

where $R_{g}$ represents global radiation $\left(\mathrm{W} \mathrm{m}^{-2}\right), F p_{\max }$ the maximum photosynthetic capacity, and $d$ is a coefficient controlling the slope of the function. These ecosystem-scale light response curves were derived using all available peak wet season daytime data.

Canopy conductance exchange with the atmosphere was calculated as proposed by Herbst et al. (2002) and Jensen and Hummelshoj (1995). This approach includes the influence of leaf area index (LAI), where only peak season values were used for analysis. For a more detailed description of the method, see Kutsch et al. (2008).

\subsubsection{Supplemental data}

In order to make the measured data available to larger spatial scales some key values were expressed relative to the fraction of absorbed photosynthetic radiation $\left(f_{\mathrm{APAR}}\right)$, a satellitederived product calculated by the Joint Research Centre (http://fapar.jrc.it/). We used peak growing season 10 day averages at 1 pixel resolution for each site.

\subsection{Results}

\subsubsection{Basic data comparison}

Like most parts of Sub-Saharan Africa, the ecosystems under consideration are characterised by a strong seasonality in moisture inputs. For the eleven sites studied, the dry season ranged from 5 months in Congo up to 7 months in Sudan. The Congo sites usually experience two wet seasons and two dry seasons per year, caused by the movement of the Intertropical Convergence Zone (ITC).

Long-term annual temperatures for all sites were ranging from $22-29^{\circ} \mathrm{C}$. In many other respects the sites differ greatly, for instance in soil, vegetation type and land use (Table 1).

The main flux results from the sites are compiled in Figs. 3-7. Figure 3 shows the relation between modelled and measured values of night-time ecosystem respiration for all sites. Light (Fig. 4), water vapour pressure deficit of the air (VPD, Fig. 5) and temperature (Fig. 6) responses of canopy photosynthesis $\left(F_{P}\right)$ are shown in the following Figures. VPD response of canopy conductance for water vapour (Fig. 7) is shown next.

Temperature has an influence on ecosystem respiration (ER) at all sites. However, for the drought-prone sites (receiving less than $1000 \mathrm{~mm}$ of annual precipitation), soil moisture eventually became an important factor even during the wet season. Only the sites in Congo were primarily driven by temperature (Fig. $3 \mathrm{j}$ and k), while soil water content did not show a convincing correlation for these sites (not shown). The lowest respiration rates during the wet season were observed at the Wankama - Millet (cropland) site in Niger with an overall average value of $2.07 \mu \mathrm{mol} \mathrm{m}^{-2} \mathrm{~s}^{-1}$ (Table 3). In contrast, the highest efflux rates were observed at Mongu, Zambia, with an overall average of $7.10 \mu \mathrm{mol} \mathrm{m}^{-2} \mathrm{~s}^{-1}$, while peaks in respiration of 10 to $20 \mu \mathrm{mol} \mathrm{m}^{-2} \mathrm{~s}^{-1}$ are not unusual at any site, in particular after rain events (Fig. 3).

The maximum canopy-scale photosynthetic rates $\left(F p_{\max }\right)$ of the various ecosystems ranged from $-12.5 \mu \mathrm{mol} \mathrm{m}^{-2} \mathrm{~s}^{-1}$ in Niger (Wankama Millet) to $-48 \mu \mathrm{mol} \mathrm{m}^{-2} \mathrm{~s}^{-1}$ at Tchizalamou, Congo (Fig. 4). Fp was found to decrease with increasing vapour pressure deficit (VPD) at all $\mathrm{C}_{3}$-plantdominated sites (Fig. 5c, d, f, g, h and i) experiencing values higher than $2.0 \mathrm{kPa}$ and receiving less than $1000 \mathrm{~mm}$ of rain per year. Especially the Kelma site in Mali showed a strong decline in photosynthetic fluxes at high values of VPD (Figs. 4 and 5g), whereas the site in Maun Botswana showed a strong decline during the wet season in 2002 but not in 2001, when precipitation during the peak growing season was much higher $(290 \mathrm{~mm}$ in $2001,109 \mathrm{~mm}$ in 2002 ; Fig. 5c). In addition, some ecosystems showed a strong relationship between canopy photosynthesis and temperature, under light saturation $\left(R_{g}>500 \mathrm{~W} \mathrm{~m}^{-2}\right)$ and moderate VPD $(<2.0 \mathrm{kPa}$, Fig. 6). At all sites, canopy conductance $(G c)$ decreased with increasing values of VPD $(>2.0 \mathrm{kPa}$, Fig. 7$)$.

\subsubsection{Integration of key values and comparison to re- mote sensing data}

Key variables such as $F p_{\max }$ and $G c_{\max }$ (here defined as canopy conductance at $F p_{\max }$ ) were analysed in relation to 


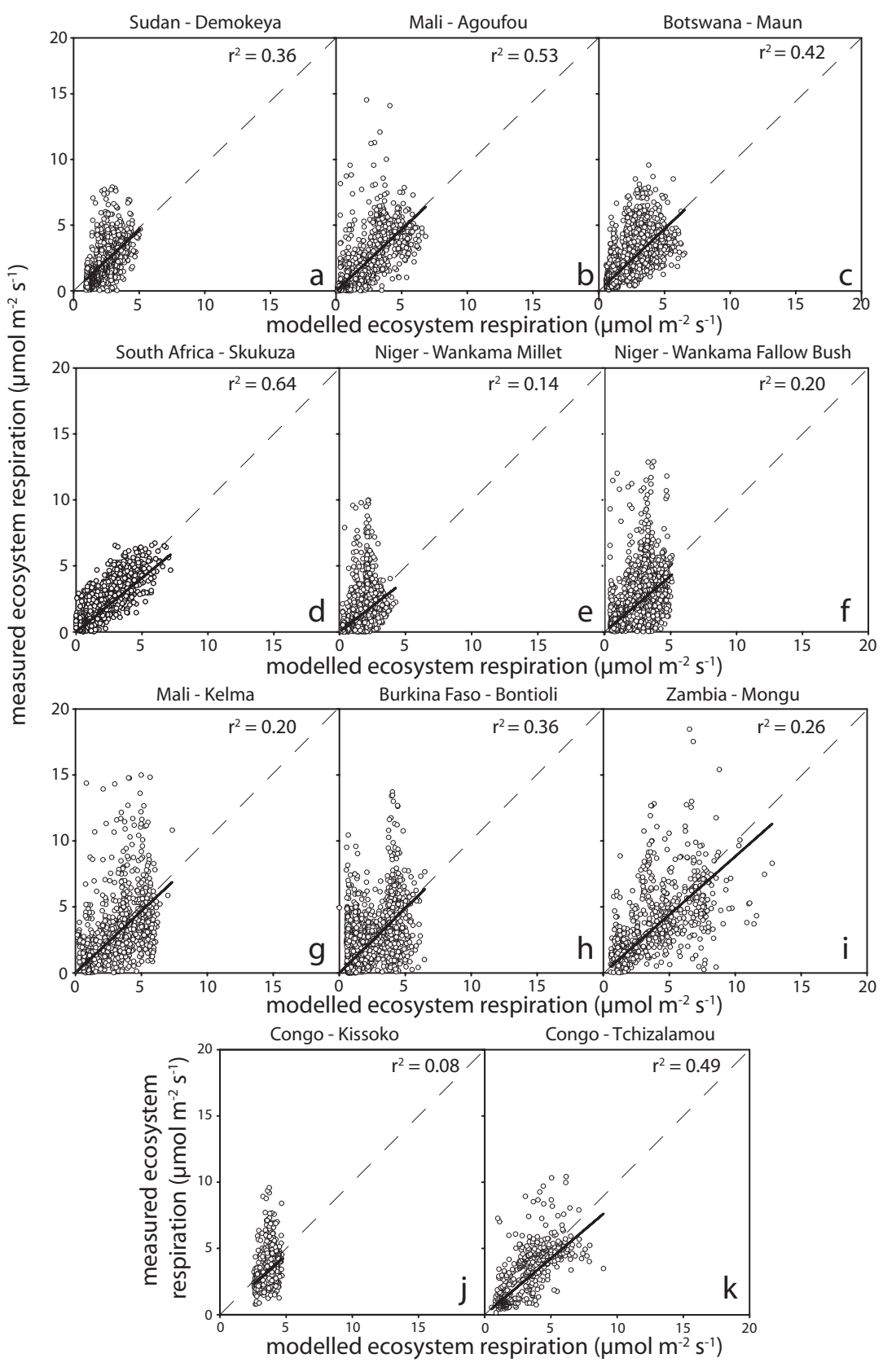

Fig. 3. Graphs (a-k) show modelled ecosystem respiration versus measured ecosystem respiration (night time data). Sites receiving more than $1000 \mathrm{~mm}$ of rain per year (Congo) were correlated with air temperature only. Peak season averages of ER for each site are given in Table 3 .

mean annual rainfall in the next step. $F p_{\max }$ was depicted as positive values from now on since we are leaving micrometeorological terrain and enter ecological interpretation. The following patterns were observed:

- Within the range of the study $(300-1200 \mathrm{~mm}$ ) we found a strong correlation between mean annual rainfall and maximum photosynthetic uptake $\left(F p_{\max }\right)$ that could be best described by an exponential growth function $\left(r^{2}=0.74\right.$, Fig. $\left.8 \mathrm{a}\right)$. Note, that the Wankama-Millet site (Niger) was excluded due to the very low stand density $\left(<10000\right.$ plants ha $\left.^{-1}\right)$ and therefore considerably smaller carbon fluxes as a result of human management (Fig. 8a). The Kelma site (Mali) was included with $650 \mathrm{~mm}$ of rainfall even though the actual precipitation is only about $350 \mathrm{~mm}$ but is characterised by an additional inflow of water $(\geq 300 \mathrm{~mm})$ due to the sites geometry. 

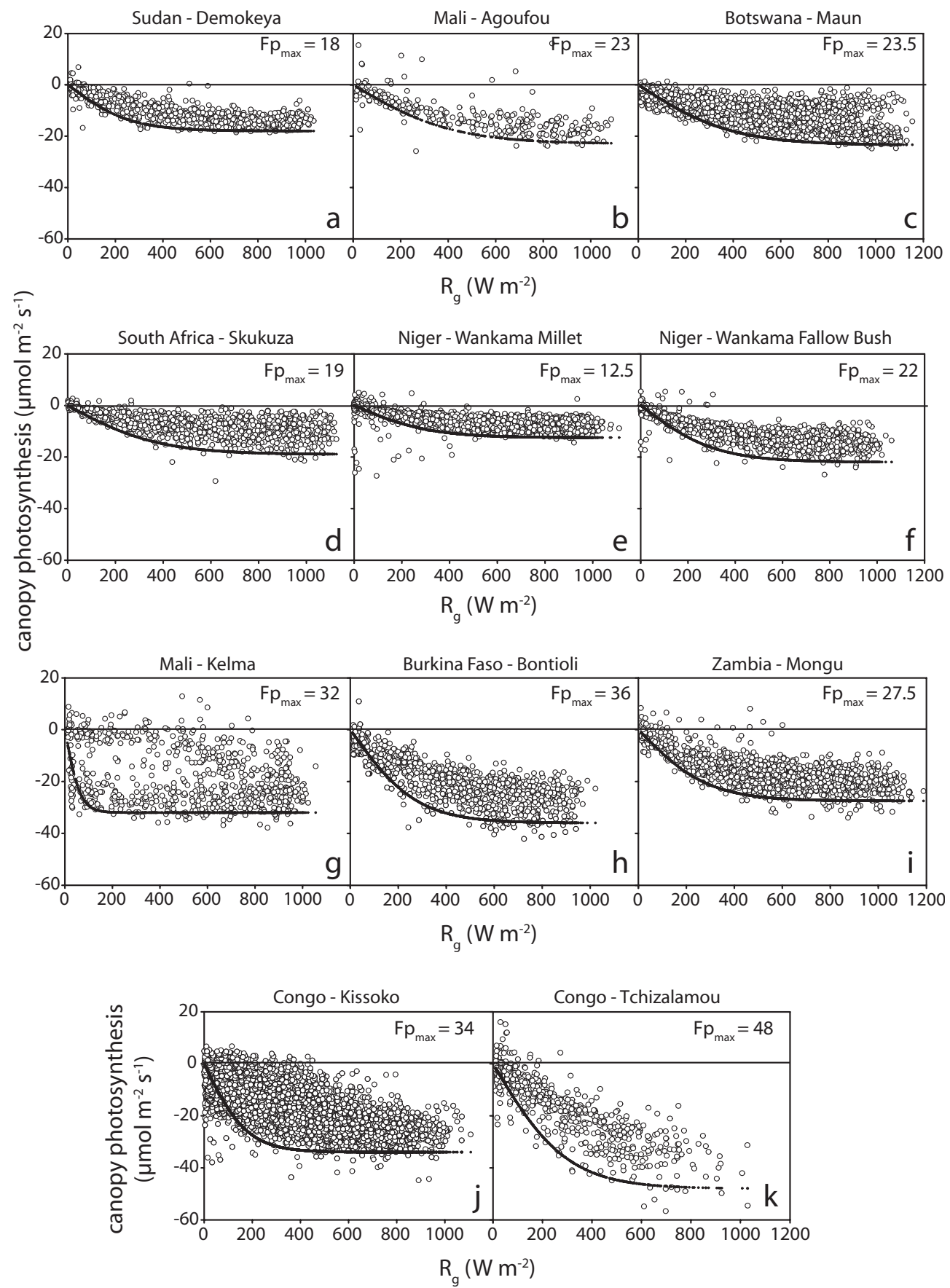

Fig. 4. (a-k): Canopy photosynthetic fluxes $(F p)$ versus global radiation $\left(R_{g}\right)$ allowing the estimation of the maximum photosynthetic uptake rate $\left(F p_{\max }\right)$.

- Maximum photosynthetic uptake is strongly related to $G c_{\max }$ (Fig. 8b). The high standard deviation in this graph results from the way we analysed the data: for all values of $F p_{\max }$ out of each dataset that were higher than $90 \%$ of the $F p_{\text {max }}$ calculated by quantile regression (see Fig. 4), $F p_{\max }$ and canopy conductance were averaged. All data with rainfall events at measurement and $6 \mathrm{~h}$ after rainfall were rejected. This was only possible when rainfall data was available. We used this procedure, since it is impossible to define the exact situation for deriving $G c_{\max }$ according to Schulze et al. (1994).

In the next step key values of the different sites were compared to $f_{\mathrm{APAR}}$ data from satellite observations. For this comparison, we distinguished between purely or almost purely grass-dominated lands $\left(\mathrm{C}_{4}\right.$-plants $)$ on one hand and 

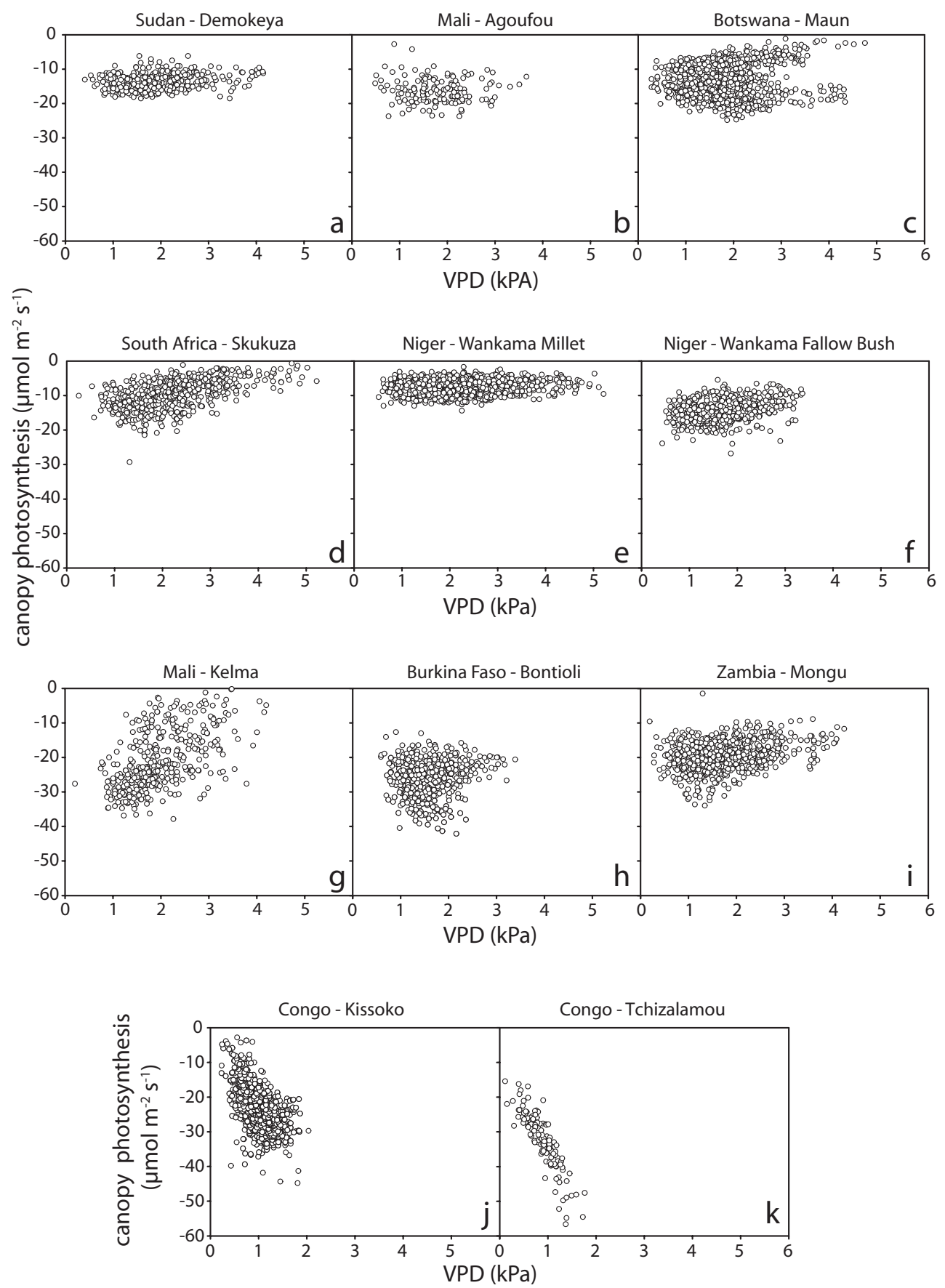

Fig. 5. (a-k): The response of light-saturated canopy photosynthetic fluxes $\left(R_{g}>500 \mathrm{~W} \mathrm{~m}^{-2}\right)$ to water vapour pressure deficit (VPD). A strong decrease in $F p$ where VPD exceeds $2.0 \mathrm{kPa}$ can be seen for several sites ( $\mathrm{C}_{3}$ dominated ecosystems).

mixed or tree-dominated $\left(\mathrm{C}_{3}\right.$-plants, further only called "tree dominated") ecosystems on the other. The following correlations were found:

- $f_{\text {APAR }}$ increased with mean annual rainfall for both groups of ecosystems (Fig. 9 a): However, the linear curves found for the two groups differed: the curve for tree-dominated ecosystems had a steeper increase, whilst the curve for the grass-dominated lands increased more smoothly. None of the curves seem to level off above a certain amount of rainfall.

- $F p_{\text {max }}$ and $f_{\text {APAR }}$ correlated linearly without leveling off within the observed range of rainfall (Fig. 9b). $F p_{\text {max }}$ increase was steeper for grass-dominated ecosystems than for tree-dominated, which may be also related 

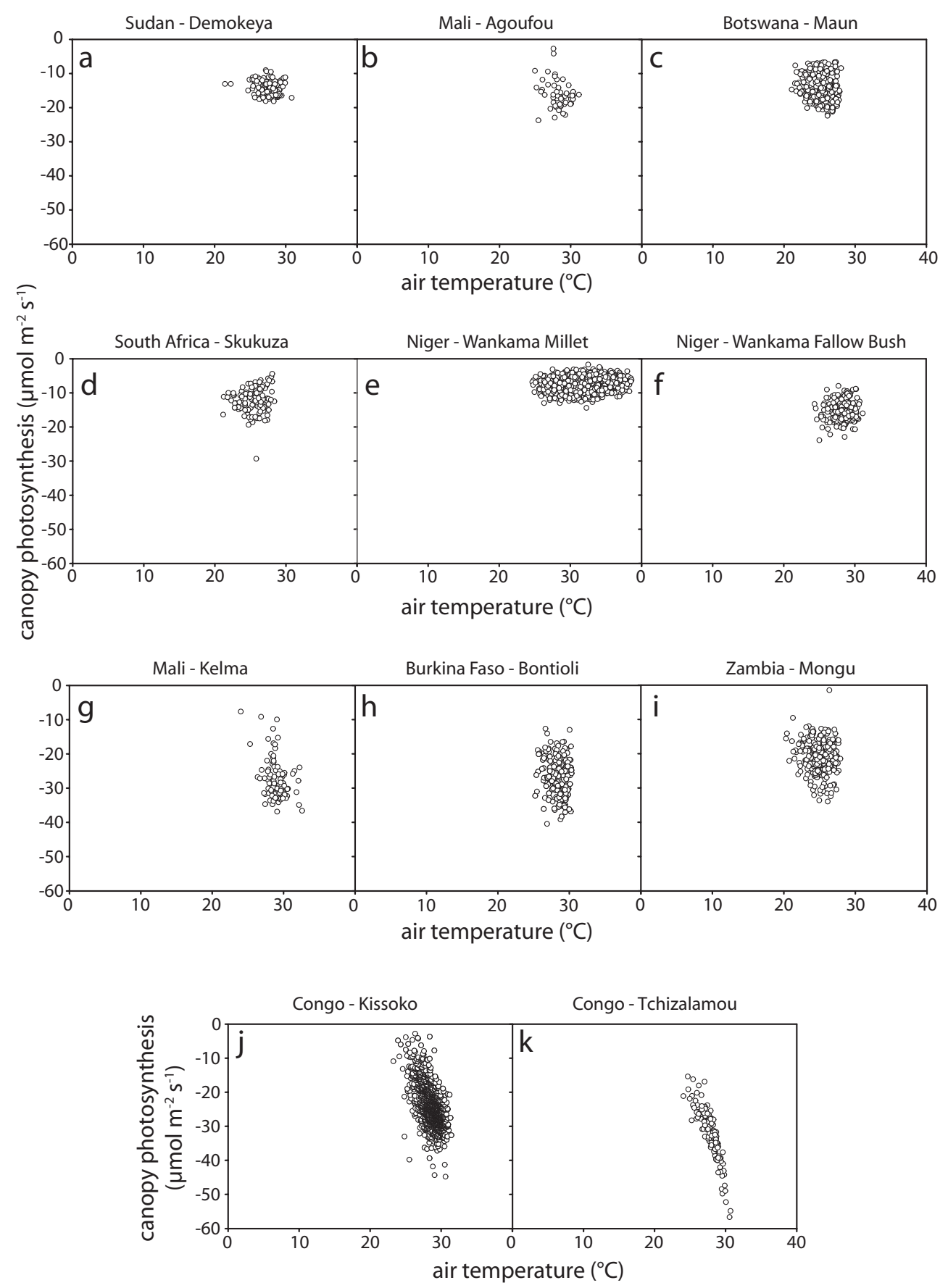

Fig. 6. (a-k): The response of light-saturated canopy photosynthetic fluxes $\left(R_{g}>500 \mathrm{~W} \mathrm{~m}^{-2}, \mathrm{VPD}<2 \mathrm{kPa}\right)$ and water vapour pressure deficit to air temperature showing a strong relation for some sites.

to differences in the photosynthetic pathways of trees $\left(\mathrm{C}_{3}\right)$ and grasses $\left(\mathrm{C}_{4}\right)$.

- A similar picture as found for the relationship between mean annual rainfall and $f_{\text {APAR }}$ (Fig. 9a), was found between peak leaf area index (LAI) and mean annual rainfall (Fig. 9c). Even though the slopes of tree dominated and grassland ecosystems vary slightly to Fig. 9a, both variables, $f_{\mathrm{APAR}}$ and peak LAI, intend to give similar results.

- Finally, to prove that $f_{\mathrm{APAR}}$ is a proxy for canopy cover and can be compared to LAI, "the eye in the sky", namely $f_{\mathrm{APAR}}$, and leaf area index (LAI) measured at 

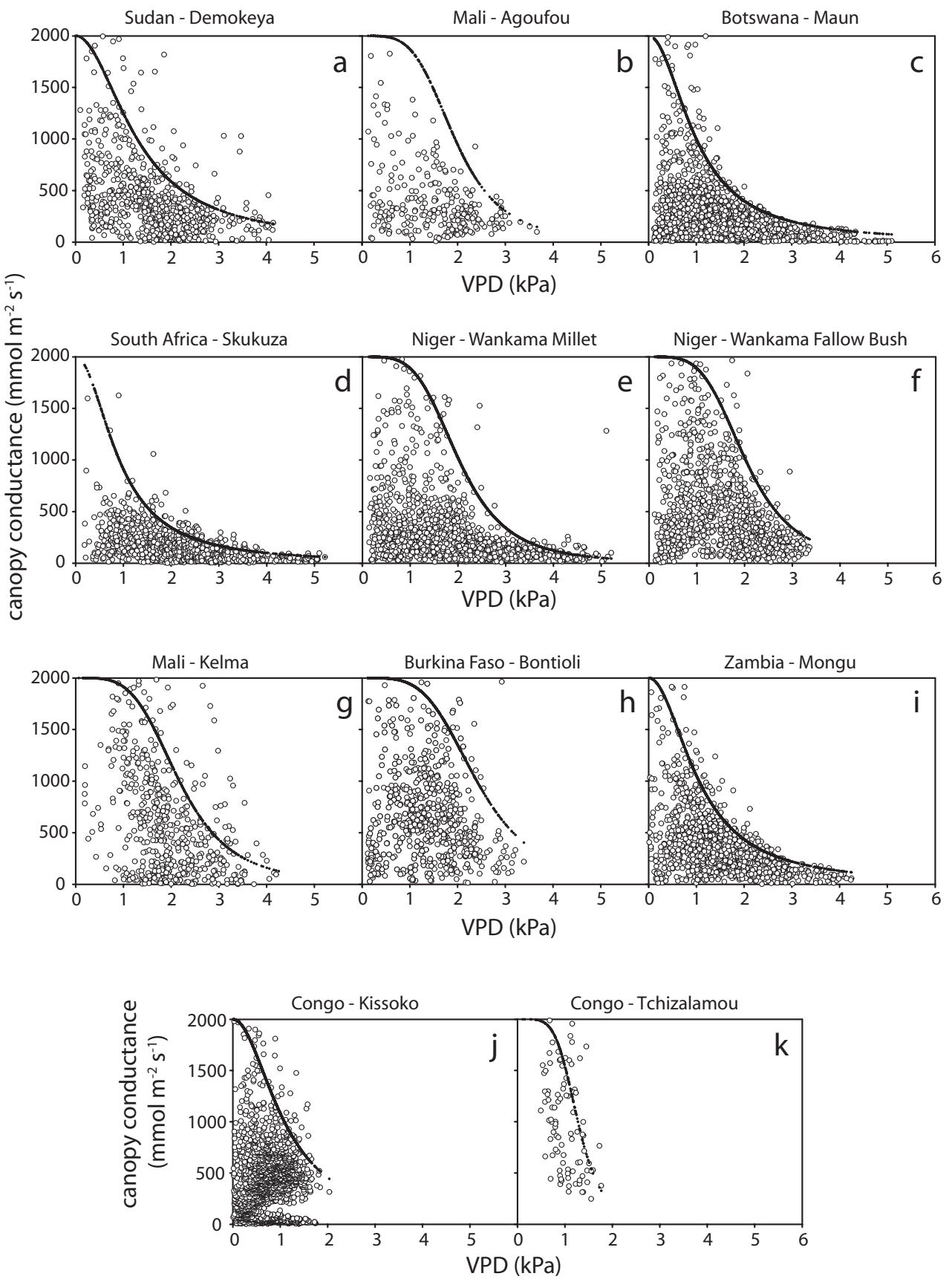

Fig. 7. (a-k): The relationship between canopy conductance and canopy photosynthesis. Canopy conductance decreases with increasing values of VPD.

the ground, correlated highly $\left(r^{2}=0.79\right.$, Fig. 9 d). The Bontioli site (Burkina Faso) was excluded since LAI measurements were taken using a different technique than at the other sites.

\subsection{Discussion}

The study combines results of eddy-covariance measurements along a rainfall gradient and through different ecosystems of Sub-Saharan Africa. Savanna ecosystems, which predominate in Africa, are thought to be a key source of 

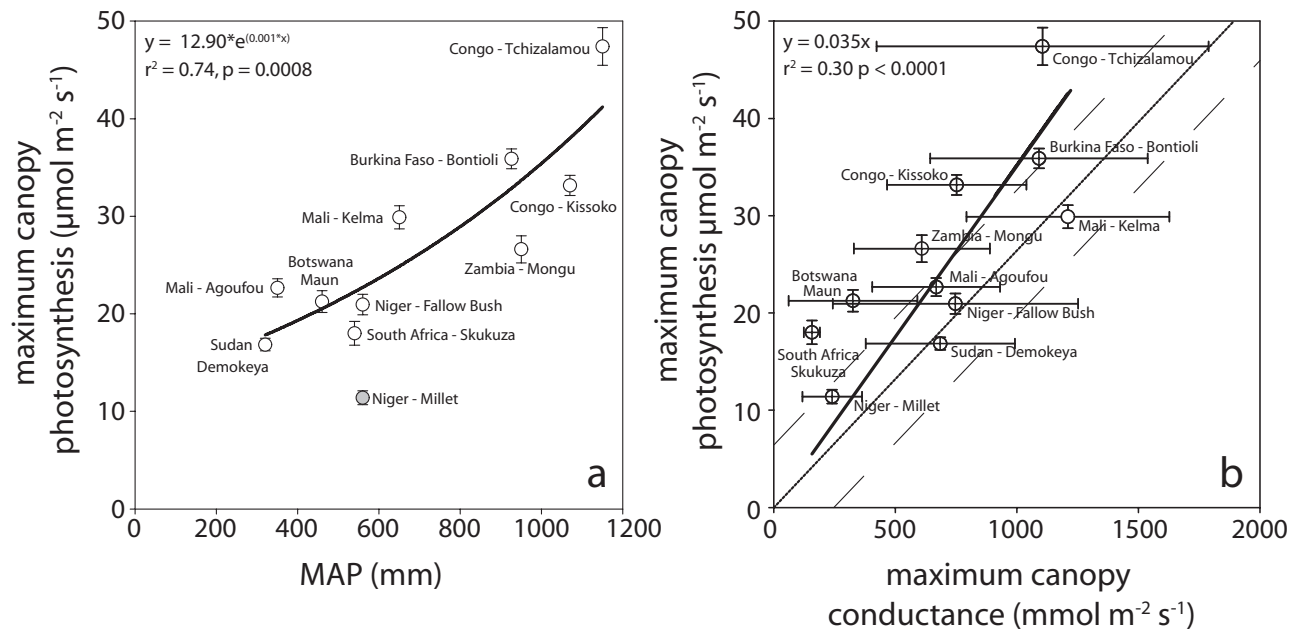

Fig. 8. (a) The derived exponential relationship of maximum canopy photosynthesis versus mean annual rainfall for 10 (Niger Millet cropland was excluded due to low stand density) African ecosystems $(n=10)$.(b)Maximum canopy conductance $\left(\mathrm{Gc}_{\max }\right)$ versus maximum photosynthetic uptake $\left(F p_{\max }\right)$ rate, both shown \pm SD. The dotted line (with the 1 SD limits dashed) shows the global relationship of $F p_{\text {max }}$ and $G c_{\max }$ found by Schulze et al. (1994) and the thick solid regression line shows the regression for the eleven African sites. $(n=11)$

variability in the global terrestrial cycles of water and carbon (Williams et al., 2007; Weber et al., 2009). Moreover, all African ecosystems will likely experience increasing climate-change-driven and human pressure in the future (Fuller and Prince, 1996; Williams et al., 2007). Improved quantification of the atmospheric carbon exchange across vegetation types thus provides fundamental information that can, for instance, be used to evaluate the performance of current terrestrial carbon cycle models. Obviously, eleven study sites cannot provide representative continental coverage, but this preliminary synthesis represents a significant advance given the paucity of information to date. We note that the examples presented here include some of the most typical natural and anthropogenic vegetation types in Sub-Saharan Africa. However, the tropical rainforests of Central Africa remain unrepresented. Measurements within the humid forests of the Congo basin will be an important future challenge.

The strong correlation discovered between maximum photosynthetic uptake $\left(F p_{\max }\right)$ and mean annual precipitation (Fig. 8a) poses the question whether this result was achieved by chance, due to the amounts of precipitation in the year under consideration being similar to the long-term averages, or whether $F p_{\text {max }}$ indeed reflects an adaptation of the ecosystem to the long-term mean of water availability (Shugart et al., 2004). The explanation for the latter hypothesis could be the fact that tree coverage and consequently the tree contribution to $F p_{\max }$ is stronger related to mean annual rainfall (Sankaran et al., 2005) and should be relatively constant inter-annually, whereas the grass layer may respond more variably to inter-annual changes in precipitation in terms of biomass, leaf area and contribution to $F p_{\text {max }}$. Analyses by Albertson et al. (2006) and Archibald and Scholes (2007) showed that inter-annual variation in integrated NDVI (used as a proxy for NPP) was almost entirely determined by the grass layer: i.e. the higher the tree cover at a site, the more consistent the phenological signal from year to year. The relatively constant leaf area of the tree layer during the growing season may explain the high correlation between $F p_{\max }$ and mean annual precipitation even if the rainfall did not match the long-term average in the year under consideration.

The relationship between annual rainfall and $F p_{\max }$ increased exponentially in our study. We assume that it would eventually saturate, forming a s-shaped curve, if sites with higher precipitation were included. Tree cover fraction do not reach a maximum within the rainfall gradient presented in this study $(320-1200 \mathrm{~mm})$, whereas other studies about tree cover already reach a maximum at $800 \mathrm{~mm}$ of rainfall (Sankaran et al., 2005; Bucini and Hanan, 2007). Studies on annual litterfall show a saturation of foliage production with mean annual precipitation only beyond $4000 \mathrm{~mm}$ (Liu et al., 2004). Annual gross primary production rises with mean annual precipitation up to at least $3000 \mathrm{~mm}$ (Luyssaert et al., 2007). This shows that tree cover may only be a weak predictor of productivity of a site.

Canopy photosynthetic capacity was strongly correlated to maximum canopy conductance $\left(G c_{\max }\right.$ at $F p_{\max }$, Fig. $\left.8 \mathrm{~b}\right)$. This was predicted by Schulze et al. (1994) in a theoretical study scaling up knowledge from leaf level measurements. The eddy covariance method may be well suited to test these predictions, after applying several quality checks to the data, e.g. when separating NEE into $F p$ and ER. The results match the predictions by Schulze et al. (1994), even though most of the sites included in this study and the regression line lie slightly above the proposed relation, which might be the consequence of a high abundance of $\mathrm{C}_{4}$ plant in Africa. The relationship between canopy conductance and 

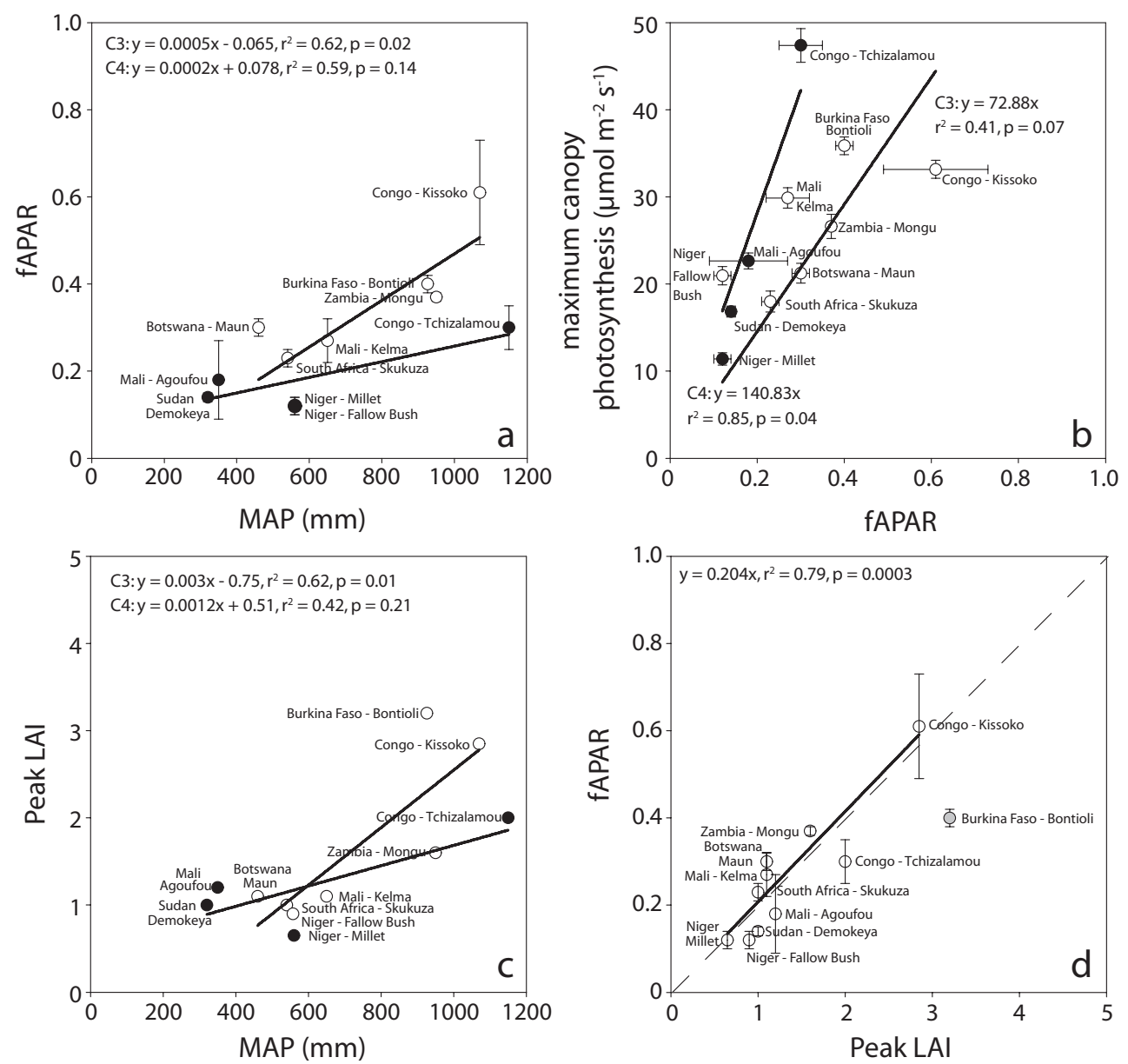

Fig. 9. (a) Relationship of satellite-derived peak $f_{\mathrm{APAR}}$ to mean annual rainfall for all sites in this study \pm SD. The tree dominated ecosystem (white circles, $\mathrm{C}_{3}, n=7$ ) differ in slope and intercept from the grasslands (black circles, $\mathrm{C}_{4}, n=4$ ) (b) The relationship between maximum canopy photosynthesis $\left(F p_{\max }\right)$ and peak $f_{\mathrm{APAR}}$ for the African sites \pm SD. Sites dominated by $\mathrm{C}_{3}$ trees have a different (steeper) slope to those dominated by $\mathrm{C}_{4}$ grasses. (c) A similar dependency as found for peak $f_{\text {APAR }}$ vs. MAP was found for ground measured peak LAI vs. MAP, resulting in slightly different slopes. (d) Correlation between ground based peak LAI and remote sensing bases peak $f_{\mathrm{APAR}}$ for 10 African ecosystems \pm SD (the Burkina Faso site was excluded since it seemed to represent an outlier, due to a different technique for estimating LAI). The dashed line represents the 5:1 line.

$F p_{\max }$ is constant over space (this study) and time (Kutsch et al., 2009). This seems to be relevant for scaling processes from leaf to ecosystem level and even to higher scales.

Since scaling is often combined with remote sensing and water and carbon fluxes depend highly on leaf area (Schulze et al., 1994; Baldocchi et al., 2001b; Nouvellon et al., 2001), we used satellite derived $f_{\text {APAR }}$ in order to further analyse our results. Fensholt et al. (2004) showed the strong connection between leaf area index (LAI), $f_{\mathrm{APAR}}$ and normalized difference vegetation index (NDVI). Plotting $f_{\text {APAR }}$ against mean annual rainfall shows a pattern that is similar to the pattern shown for tree cover versus mean annual rainfall by Sankaran et al. (2005). Grass-dominated sites showed a lower slope than the more wooded systems (Fig. 9a) but may reach a similar $f_{\mathrm{APAR}}$ at higher mean annual rainfall.
This was the rationale for distinguishing between tree(predominantly $\mathrm{C}_{3}$ ) and grass-dominated (predominately $\mathrm{C}_{4}$ ) ecosystems when plotting $F_{\mathrm{Pmax}}$ against $f_{\mathrm{APAR}}$. Sites mainly consisting of $\mathrm{C}_{4}$ plants (grassland and croplands) showed a stronger increase in $F_{\text {Pmax }}$ with $f_{\mathrm{APAR}}$ than $\mathrm{C}_{3}$ dominated sites (Fig. 9 b). The Sudan site, which is sparsely covered with $\mathrm{C}_{3}$ Acacia trees (less than $30 \%$ ) with an understory of $\mathrm{C}_{4}$ grasses contributing the majority of the measured fluxes, was treated as a $\mathrm{C}_{4}$ dominated ecosystem.

The relation found between LAI and $f_{\mathrm{APAR}}$ underpins the value os $f_{\mathrm{APAR}}$ as a proxy from remote sensing. The linear relationship is supposed to level off towards higher values of LAI ( $\geq 4.5$; Gobron et al., 2006), which were not reached in this study. 


\section{Conclusion and Outlook}

In this study, we present a first integration of water and carbon fluxes in African ecosystems. Within a rainfall gradient between $320-1150 \mathrm{~mm}$ the data showed a strong dependency of carbon fluxes on water relations. In particular, the strong correlation between maximum canopy photosynthetic capacity and mean annual rainfall revealed valuable insights in ecosystem functioning in semi-arid environments. However, we could only speculate about the ecophysiological mechanisms underlying our observations, even though we matched theoretical predictions based on global eco-physiological knowledge. We suggest that more groundbased measurements should be combined with modelling approaches and remote sensing. By showing that $f_{\mathrm{APAR}}$ provides a good measure for the spatial distribution of canopy photosynthetic capacity, we presented an important finding for scaling to regional or even continental scale in Africa. Comparing other remote sensing indices (i.e. EVI, Sjöström et al., 2009) to ground based flux measurements may even improve our knowledge about African carbon cycle dynamics.

Acknowledgements. This data integration study has been part of the CarboAfrica Initiative (EU, Contract No: 037132), using data from flux towers in Congo, South Africa, Sudan and Zambia that are currently under direct CarboAfrica support. Nevertheless, we are thankful that we received data from other sites or earlier projects that were supported by other international or national projects:

Work of J. Ardö at the Sudan site was supported by the Swedish Science Council (contract 2004-3888).

The South African flux site was initiated and maintained with funding from NASA and the SA governmental LEAD programme, from the US National Science Foundation Grant EAR-0120630 Biocomplexity in African savannas (PI: Nial Hanan), and from the NOAA Grant NA17RJ1228. Current operation occurs with help from the SA Department of Science and Technology and the CarboAfrica programme.

Studies carried out at the Congolese sites were funded by the Observatoire de Recherche en Environnement F-ORE-T and the European Integrated Project Ultra Low $\mathrm{CO}_{2}$ Steelmaking (ULCOS—Contract no. 515960 ).

Funding for the research at Burkina Faso was provided by the Helmholtz Association of German Research Centers (Virtual Institute, VH-VI-001).

German Science Foundation supported research of W. Kutsch at the Skukuza flux tower site in South Africa (DFG Ku 1099/2-1).

We also thank The Max-Planck Institute for Biogeochemistry, in particular the field experiments group, for providing additional funding and instruments for the newly established site in Mongu, Zambia and Corinna Rebman for help during data post processing.

The service charges for this open access publication have been covered by the Max Planck Society.

Edited by: G. Wohlfahrt

\section{References}

Albertson, J. D., Williams, C. A., Scanlon, T. M., and Montaldo, N.: Soil moisture controls on water vapor and carbon fluxes in semi-arid regions, Dryland Ecohydrol., 67-83, 2006.

Anthoni, P. M., Knohl, A., Rebmann, C., Freibauer, A., Mund, M., Ziegler, W., Kolle, O., and Schulze, E. D.: Forest and agricultural land-use-dependent $\mathrm{CO}_{2}$ exchange in Thuringia, Germany, Global Change Biol., 10, 2005-2019, 2004.

Archibald, S. and Scholes, R. J.: Leaf green-up in a semi-arid African savanna - separating tree and grass responses to environmental cues, J. Veg. Sci., 18, 583-594, 2007.

Arneth, A., Veenendaal, E. M., Best, C., Timmermans, W., Kolle, O., Montagnani, L., and Shibistova, O.: Water use strategies and ecosystem-atmosphere exchange of $\mathrm{CO}_{2}$ in two highly seasonal environments, Biogeosciences, 3, 421-437, 2006, http://www.biogeosciences.net/3/421/2006/.

Aubinet, M., Grelle, A., Ibrom, A., Rannik, U., Moncrieff, J., Foken, T., Kowalski, A. S., Martin, P. H., Berbigier, P., Bernhofer, C., Clement, R., Elbers, J., Granier, A., Grünwald, T., Morgenstern, K., Pilegaard, K., Rebmann, C., Snijders, W., Valentini, R., and Vesala, T.: Estimates of the annual net carbon and water exchange of forests: The Euroflux methodology, Adv. Ecol. Res., 30, 113-175, 2000.

Baldocchi, D., Finnigan, J., Wilson, K., Paw, U. K. T., and Falge, E.: On measuring net ecosystem carbon exchange over tall vegetation on complex terrain, Bound.-Lay. Meteor., 96, 257-291, 2000.

Baldocchi, D., Falge, E., Gu, L. H., Olson, R., Hollinger, D., Running, S., Anthoni, P., Bernhofer, C., Davis, K., Evans, R., Fuentes, J., Goldstein, A., Katul, G., Law, B., Lee, X. H., Malhi, Y., Meyers, T., Munger, W., Oechel, W., Paw U, K. T., Pilegaard, K., Schmid, H. P., Valentini, R., Verma, S., Vesala, T., Wilson, K., and Wofsy, S.: Fluxnet: A new tool to study the temporal and spatial variability of ecosystem-scale carbon dioxide, water vapor, and energy flux densities, B. Amer. Meteor. Soc., 82, 2415-2434, 2001a.

Baldocchi, D., Falge, E., and Wilson, K.: A spectral analysis of biosphere-atmosphere trace gas flux densities and meteorological variables across hour to multi-year time scales, Agr. For. Meteorol., 107, 1-27, 2001b.

Bond, W. J. and Keeley, J. E.: Fire as a global 'herbivore': The ecology and evolution of flammable ecosystems, Trends in Ecology \& Evolution, 20, 387-394, 2005.

Bond, W. J., Woodward, F. I., and Midgley, G. F.: The global distribution of ecosystems in a world without fire, New Phytol., 165, 525-537, 2005.

Boulain, N., Cappelaere, B., Ramier, D., Issoufou, H. B. A., Halilou, O., Seghieri, J., Guillemin, F., Ö̈, M., Gignoux, J., and Timouk, F.: Towards an understanding of coupled physical and biological processes in the cultivated Sahel -2 . Vegetation and carbon dynamics, J. Hydrol., doi:10.1016/j.jhydrol.2008.11.045, 2009.

Bruemmer, C., Falk, U., Papen, H., Szarzynski, J., Wassmann, R., and Brueggemann, N.: Diurnal, seasonal, and interannual variation in carbon dioxide and energy exchange in shrub savanna in Burkina Faso (West Africa), J. Geophys. Res., 113, G02030, doi:10.1029/2007JG000583, 2008.

Bucini, G. and Hanan, N. P.: A continental-scale analysis of tree cover in African savannas, Global Ecol. Biogeogr., 16, 593-605, 
2007.

Cade, B. S., Noon, B. R., and Flather, C. H.: Quantile regression reveals hidden bias and uncertainty in habitat models, Ecology, 86, 786-800, 2005.

Dolman, A. J., Gash, J. H. C., Goutorbe, J. P., Kerr, Y., Lebel, T., Prince, S. D., and Stricker, J. N. M.: The role of the land surface in Sahelian climate: Hapex-Sahel results and future research needs, J. Hydrol., 188-189, 1067-1079, 1997.

Dolman, A. J., Schulze, E. D., and Valentini, R.: Analyzing carbon flux measurements, Science, 301, 916-916, 2003.

Epron, D., Ngao, J., and Granier, A.: Interannual variation of soil respiration in a beech forest ecosystem over a six-year study, Ann. For. Sci., 61, 499-505, 2004.

Epron, D., Nouvellon, Y., Deleporte, P., Ifo, S., Kazotti, G., M'Bou, A. T., Mouvondy, W., Saint Andre, L., Roupsard, O., Jourdan, C., and Hamel, O.: Soil carbon balance in a clonal eucalyptus plantation in Congo: Effects of logging on carbon inputs and soil $\mathrm{CO}_{2}$ efflux, Glob. Change Biol., 12, 1021-1031, 2006.

Fensholt, R., Sandholt, I., and Rasmussen, M. S.: Evaluation of modis lai, fapar and the relation between fAPAR and NDVI in a semi-arid environment using in situ measurements, Remote Sens. Environ., 91, 490-507, 2004.

Fuller, D. O. and Prince, S. D.: Rainfall and foliar dynamics in tropical southern africa: Potential impacts of global climatic change on savanna vegetation, Clim. Change, 33, 69-96, 1996.

Gobron, N., Pinty, B., Aussedat, O., Chen, J.M., Cohen, W.B., Fensholt, R., Gond, V., Huemmrich, K.F., Lavergne, T., Malin, F., Privette, J.L., Sandholt, I., Taberner, M., Turner, D.P., Verstraete, M.M., Widlowski, J.-L.:Evaluation of fraction of absorbed photosynthetically active radiation products for different canopy radiation transfer regimes: Methodology and results using Joint Research Center products derived from SeaWiFS against ground-based estimations, J. Geophys. Res., 111, D13110, doi:10.1029/2005JD006511, 2006.

Goulden, M. L., Munger J. W., Fan, S.-M., Daube, B. C., and Wofsky, S. : Measurements of carbon sequestration by long-term eddy covariance: Methods and critical evaluation of accuracy, Glob. Change Biol., 2, 169-182, 1996.

Goutorbe, J. P., Lebel, T., Dolman, A. J., Gash, J. H. C., Kabat, P., Kerr, Y. H., Monteny, B., Prince, S. D., Stricker, J. N. M., Tinga, A., and Wallace, J. S.: An overview of Hapex-Sahel: A study in climate and desertification, J. Hydrol., 188-189, 4-17, 1997.

Gu, L. H., Falge, E. M., Boden, T., Baldocchi, D. D., Black, T. A., Saleska, S. R., Suni, T., Verma, S. B., Vesala, T., Wofsy, S. C., and $\mathrm{Xu}, \mathrm{L}$. K.: Objective threshold determination for nighttime eddy flux filtering, Agr. For. Meteorol., 128, 179-197, 2005

Hanan, N. P., Kabat, P., Dolman, A. J., and Elbers, J. A.: Photosynthesis and carbon balance of a Sahelian fallow savanna, Global Change Biol., 4, 523-538, 1998

Herbst, M., Kutsch, W. L., Hummelshoj, P., Jensen, N. O., and Kappen, L.: Canopy physiology: Interpreting the variations in eddy fluxes of water vapour and carbon dioxide observed over a beech forest, Basic Appl. Ecol., 3, 157-169, 2002.

Hudman, L. E. and Jackson, R. H.: Geography of travel and tourism, Thomson/Delmar Learning ed., Clifton Park, NY: Thomson/Delmar Learning, 544 pp., 2002.

Jeltsch, F., Weber, G. E., and Grimm, V.: Ecological buffering mechanisms in savannas: A unifying theory of long-term treegrass coexistence, Plant Ecol., 150, 161-171, 2000.
Jensen, N. O. and Hummelshoj, P.: Derivation of canopy resistance for water vapour fluxes over a spruce forest, using a new technique for the viscous sublayer resistance, Agricult. For. Meteorol., 73, 339-352, 1995.

Kolle, O. and Rebmann, C.: Eddysoft - documentation of a software package to acquire and process eddy covariance data, Technical Reports - Max-Planck-Institut für Biogeochemie, 10, 88 pp., 2007.

Kutsch, W. L., Hanan, N., Scholes, R. J., McHugh, I., Kubheka, W., Eckhardt H., and Williams, C.: Response of carbon fluxes to water relations in a savanna ecosystem in South Africa, Biogeosciences, 5, 1797-1808, 2008,

http://www.biogeosciences.net/5/1797/2008/.

Leuning, R. and Moncrieff, J.: Eddy-covariance $\mathrm{CO}_{2}$ flux measurements using open-path and closed-path $\mathrm{CO}_{2}$ analyzers - corrections for analyzer water-vapor sensitivity and damping of fluctuations in air sampling tubes, Bound.-Layer Meteor., 53, 63-76, 1990.

Leuning, R.: The correct form of the Webb, Pearman and Leuning equation for eddy fluxes of trace gases in steady and non-steady state, horizontally homogeneous flows, Bound.-Layer Meteor., 123, 263-267, 2007.

Liu, C. J., Westman, C. J., Berg, B., Kutsch, W., Wang, G. Z., Man, R. Z., and Ilvesniemi, H.: Variation in litterfall-climate relationships between coniferous and broadleaf forests in eurasia, Global Ecol. Biogeogr., 13, 105-114, 2004.

Lloyd, J. and Farquhar, G. D.: C-13 discrimination during $\mathrm{CO}_{2}$ assimilation by the terrestrial biosphere, Oecologia, 99, 201-215, 1994.

Lloyd, J., Bird, M. I., Vellen, L., Miranda, A. C., Veenendaal, E. M., Djagbletey, G., Miranda, H. S., Cook, G., and Farquhar, G. D.: Contributions of woody and herbaceous vegetation to tropical savanna ecosystem productivity: A quasi-global estimate, Tree Physiol., 28, 451-468, 2008.

Luyssaert, S., Inglima, I., Jung, M., Richardson, A. D., Reichstein, M., Papale, D., Piao, S., Schulze, E. D., Wingate, L., Matteucci, G., Aragao, L., Aubinet , M., Beer, C., Bernhofer, C., Black, K. G., Bonal, D., Bonnefond, J.-M., Chambers, J., Ciais, P., Cook, B., Davis, K. J., Dolman, A. J., Gielen, B., Goulden, M., Grace, J., Granier, A., Grelle, A., Griffis, T., Grünwald, T., Guidolotti, G., Hanson, P. J., Harding, R., Hollinger, D. Y., Hutyra, L. R., Kolari, P., Kruijt, B., Kutsch, W., Lagergren, F., Laurila, T., Law, B. E., Le Maire, G., Lindroth, A., Loustau, D., Malhi, Y., Mateus, J., Migliavacca, M., Misson, L., Montagnani, L., Moncrieff, J., Moors, E., Munger, J. W., Nikinmaa, E., Ollinger, S. V., Pita, G., Rebmann, C., Roupsard, O., Saigusa, N., Sanz, M. J., Seufert, G., Sierra, C., Smith, M.-L., Tang, J., Valentini, R., Vesala, T., and Janssens, I. A.: The $\mathrm{CO}_{2}$-balance of boreal, temperate and tropical forests derived from a global database, Glob. Change Biol., 13, 2509-2537, 2007.

Marsden, C., Nouvellon, Y., Bou, A. T. M., Saint-Andre, L., Jourdan, C., Kinana, A., and Epron, D.: Two independent estimations of stand-level root respiration on clonal Eucalyptus stands in Congo: up scaling of direct measurements on roots versus the trenched-plot technique, New Phytol., 177, 676-687, 2008.

Merbold, L., Kutsch, W. L., Kolle, O., Zimov, S. A., Corradi, C., and Schulze, E.-D.: Artificial drought and associated carbon fluxes $\left(\mathrm{CO}_{2} / \mathrm{CH}_{4}\right)$ in tundra ecosystem, Global Change Biol., in press, doi:10.1111/j.1365-2486.2009.01962.x, 2009. 
Nouvellon, Y., Moran, M. S., Lo Seen, D., Bryant, R., Rambal, S., Ni, W. M., Begue, A., Chehbouni, A., Emmerich, W. E., Heilman, P., and Qi, J. G.: Coupling a grassland ecosystem model with Landsat imagery for a 10-year simulation of carbon and water budgets, Remote Sens. Environ., 78, 131-149, 2001.

Papale, D., Reichstein, M., Aubinet, M., Canfora, E., Bernhofer, C., Kutsch, W., Longdoz, B., Rambal, S., Valentini, R., Vesala, T., and Yakir, D.: Towards a standardized processing of net ecosystem exchange measured with eddy covariance technique: Algorithms and uncertainty estimation, Biogeosciences, 3, 571-583, 2006,

http://www.biogeosciences.net/3/571/2006/.

Ramier, D., Boulain, N., Cappelaere, B., Timouk, F., Rabanit, M., Lloyd, C.R., Boubkraoui, S., Métayer, F., Descroix, L., and Wawrzyniak, V.: Towards an understanding of coupled physical and biological processes in the cultivated Sahel 1. Energy and water, J. Hydrol., in press, corrected proof, doi:10.1016/j.jhydrol.2008.12.002, 2009.

Reichstein, M., Rey, A., Freibauer, A., Tenhunen, J., Valentini, R., Banza, J., Casals, P., Cheng, Y. F., Grunzweig, J. M., Irvine, J., Joffre, R., Law, B. E., Loustau, D., Miglietta, F., Oechel, W., Ourcival, J. M., Pereira, J. S., Peressotti, A., Ponti, F., Qi, Y., Rambal, S., Rayment, M., Romanya, J., Rossi, F., Tedeschi, V., Tirone, G., Xu, M., and Yakir, D.: Modeling temporal and largescale spatial variability of soil respiration from soil water availability, temperature and vegetation productivity indices, Global Biogeochem. Cy., 17(4), 1104, doi:10.1029/2003GB002035, 2003.

Reichstein, M., Falge, E., Baldocchi, D., Papale, D., Aubinet, M., Berbigier, P., Bernhofer, C., Buchmann, N., Gilmanov, T., Granier, A., Grunwald, T., Havrankova, K., Ilvesniemi, H., Janous, D., Knohl, A., Laurila, T., Lohila, A., Loustau, D., Matteucci, G., Meyers, T., Miglietta, F., Ourcival, J. M., Pumpanen, J., Rambal, S., Rotenberg, E., Sanz, M., Tenhunen, J., Seufert, G., Vaccari, F., Vesala, T., Yakir, D., and Valentini, R.: On the separation of net ecosystem exchange into assimilation and ecosystem respiration: Review and improved algorithm, Glob. Change Biol., 11, 1424-1439, 2005.

Sankaran, M., Hanan, N. P., Scholes, R. J., Ratnam, J., Augustine, D. J., Cade, B. S., Gignoux, J., Higgins, S. I., Le Roux, X., Ludwig, F., Ardo, J., Banyikwa, F., Bronn, A., Bucini, G., Caylor, K. K., Coughenour, M. B., Diouf, A., Ekaya, W., Feral, C. J., February, E. C., Frost, P. G. H., Hiernaux, P., Hrabar, H., Metzger, K. L., Prins, H. H. T., Ringrose, S., Sea, W., Tews, J., Worden, J., and Zambatis, N.: Determinants of woody cover in African savannas, Nature, 438, 846-849, 2005.

Sankaran, M., Ratnam, J., and Hanan, N.: Woody cover in African savannas: The role of resources, fire and herbivory, Global Ecol. Biogeogr., 17, 236-245, 2008.

Scanlon, T. M. and Albertson, J. D.: Canopy scale measurements of $\mathrm{CO}_{2}$ and water vapor exchange along a precipitation gradient in Southern Africa, Glob. Change Biol., 10, 329-341, 2004.

Scholes, R. J. and Walker, B. H.: An African savanna - synthesis of the Nylsvley study, Cambridge University Press, Cambridge, 306 pp., 1993.
Scholes, R. J. and Archer, S. R.: Tree-grass interactions in savannas, Ann. Rev. Ecol. System., 28, 517-544, 1997.

Scholes, R. J., Frost, P. G. H., and Tian, Y. H.: Canopy structure in savannas along a moisture gradient on Kalahari sands, Glob. Change Biol., 10, 292-302, 2004.

Schulze, E. D., Kelliher, F. M., Körner, C., Lloyd, J., and Leuning, R.: Relationships among maximum stomatal conductance, ecosystem surface conductance, carbon assimilation rate, and plant nitrogen nutrition - a global ecology scaling exercise, Ann. Rev. Ecol. System., 25, 629-660, 1994.

Schuttemeyer, D., Moene, A. F., Holtslag, A. A. M., De Bruin, H. A. R., and De Giesen, N. V.: Surface fluxes and characteristics of drying semi-arid terrain in West Africa, Bound.-Layer Meteor., 118, 583-612, 2006.

Serrano-Ortiz, P., Kowalski, A. S., Domingo, F., Ruiz, B., and Alados-Arboledas, L.: Consequences of uncertainties in $\mathrm{CO}_{2}$ density for estimating net ecosystem $\mathrm{CO}_{2}$ exchange by open-path eddy covariance, Bound.-Layer Meteor., 126, 209-218, 2008.

Shugart, H. H., Macko, S. A., Lesolle, P., Szuba, T. A., Mukelabai, M. M., Dowty, P., and Swap, R. J.: The SAFARI 2000 - Kalahari transect wet season campaign of year 2000, Glob. Change Biol., 10, 273-280, 2004.

Sjöström, M., Ardö, J., Eklundh, L., El-Tahir, B. A., EL-Khidir, H. A. M., Pilesjö, P., and Seaquist, J.: Evaluation of satellite based indices for primary production estimates in a sparse savanna in the Sudan, Biogeosciences, 6, 129-138, 2009, http://www.biogeosciences.net/6/129/2009/.

Trumbore, S.: Carbon respired by terrestrial ecosystems - recent progress and challenges, Glob. Change Biol., 12, 141-153, 2006.

Veenendaal, E. M., Kolle, O., and Lloyd, J.: Seasonal variation in energy fluxes and carbon dioxide exchange for a broad-leaved semi-arid savanna (mopane woodland) in Southern Africa, Glob. Change Biol., 10, 318-328, 2004.

Walter, H.: Grasland, Savanne und Busch der arideren Teile Afrikas in ihrer ökologischen Be-dingtheit, Jahrb. Wiss. Bot., 87, 750860, 1939.

Walter, H.: Ecology of tropical and subtropical vegetation. Oliver and Boyd, Edinburgh, UK, 688 pp., 1971.

Webb, E. K., Pearman, G. I., and Leuning, R.: Correction of flux measurements for density effects due to heat and water-vapor transfer, Q. J. Roy. Meteor. Soc., 106, 85-100, 1980.

Webb, E. K.: On the correction of flux measurements for effects of heat and water-vapor transfer, Bound.-Layer Meteor., 23, 251254, 1982.

Weber, U., Jung, M., Reichstein, M., Beer, C., Braakhekke, M., Lehsten, V., Ghent, D., Kaduk, J., Viovy, N., and Ciais, P.: Interannual variability of the terrestrial African carbon balance - a model intercomparison, Biogeosciences, 6, 285-295, 2009, http://www.biogeosciences.net/6/285/2009/.

Williams, C., Hanan, N., Neff, J., Scholes, R., Berry, J., Denning, A. S., and Baker, D.: Africa and the global carbon cycle, Carbon Balance and Management, 2:3, doi:10.1186/1750-0680-2-3, 2007. 